Bangladesh J. Plant Taxon. 17(2): 167-181, 2010 (December)

(C) 2010 Bangladesh Association of Plant Taxonomists

\title{
ADDITIONS TO THE ANGIOSPERMIC FLORA OF RUNCTIA SAL FOREST, BANGLADESH
}

\author{
Md. Oliur Rahman, Md. Zashim Uddin ${ }^{1}$, Ershad Tutul, Momtaz Begum \\ AND MD. ABul Hassan \\ Department of Botany, University of Dhaka, Dhaka 1000, Bangladesh
}

Keywords: Angiosperms; Runctia sal forest; Addition.

\begin{abstract}
In the present paper additional occurrence of 100 species in 75 genera under 40 angiosperm families in the Runctia Sal Forest of Sherpur district is reported. Of these, 71 species in 56 genera are from Magnoliopsida (Dicots) and 29 species in 19 genera are from Liliopsida (Monocots). These species exhibit in diverse life forms in the area, viz., 54 species are herbs, 21 species shrubs, 12 species climbers and 13 trees. Holigarna longifolia is threatened in the Sal forest area which needs to give conservation priorities. An enumeration of the species recorded is presented with important synonyms, Bengali names, habit, habitat and representative specimens.
\end{abstract}

\section{Introduction}

The Runctia Sal Forest in Sherpur district of Bangladesh is a type of deciduous forest. The floristic diversity of the forest has recently been studied and two subsequent reports on the Magnoliopsida and Liliopsida have been published with the occurrence of 153 and 49 species respectively (Tutul et al. 2009, 2010). Details about the forest have been stated in Tutul et al. (2009). Further investigation to the same forest area has been carried out for extensive survey and collection of additional species which have not been able to collect in the previous field trips. The determination of collected specimens was made and a total of 100 species are recognized, as additions to the previous accounts.

\section{Materials and Methods}

The specimens were collected from different habitats of the forest including forest floors, plain lands, forest margins, streams, swamps, hill slopes and hill tops during 20092010. The specimens were identified at Dhaka University Herbarium (DUH), currently known as Salar Khan Herbarium and identifications were confirmed by consulting Hooker (1872-1897), Prain (1903), Kanjilal et al. (1934, 1938, 1939, 1940), Dassanayake and Fosberg (1980-1985), Khan (1972-1987), Khan and Rahman (1989-2002), Hajra et al. (1997) and Singh et al. (2000). The voucher specimens were kept at the Salar Khan Herbarium. An enumeration of these species is prepared with updated nomenclature, important synonyms, habit, habitat, representative specimen and Bengali names (wherever available) of each taxon. In the enumeration, the arrangement of the families is followed according to the system of Cronquist (1981).

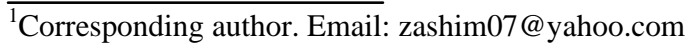




\section{Taxonomic Enumeration}

\section{MAGNOLIOPSIDA (DICOTS)}

\section{Annonaceae}

Miliusa velutina (Dunal) Hook. f. \& Thom., Fl. Ind.: 139 (1855). Uvaria velutina Dunal (1817). Local name: Gandhi-gajari.

A deciduous tree. On the forest floor. Representative specimen: Runctia, 1.11.2009, Ershad Tutul 609 (DUH).

\section{Lauraceae}

Dehaasia kurzii King ex Hook. f., Fl. Brit. Ind. 5: 125 (1886). Local name: Modonmosto.

An evergreen tree with subverticillate leaves. On the hill slope. Representative specimen: Gazni, 31.10.2009, Ershad Tutul 487 (DUH).

\section{Moraceae}

Ficus hispida L. f., Suppl. Pl.: 442 (1781). Ficus oppositifolia Roxb. (1798).

A large shrub to small tree. On the hill slope. Representative specimen: Gazni, 31.10.2009, Ershad Tutul 423 (DUH).

Ficus semicordata Buch.-Ham. ex Smith in Rees, Cycl. 14: Ficus n. 71 (1810). Ficus cunia Buch.-Ham. ex Roxb. (1832).

A small tree. On the hill slope. Representative specimen: Gazni, 31.10.2009, Ershad Tutul 462 (DUH).

Ficus religiosa L., Sp. Pl.: 1059 (1753). Urostigma religiosum (L.) Gasp. (1853). Local name: Ashwatha.

A medium-sized to large deciduous tree. On the hill slope. Representative specimen: Runctia, 1.11.2009, Ershad Tutul 573 (DUH).

\section{Urticaceae}

Sarcochlamys pulcherrima Gaudich., Voy. Bot.: t. 89 (1826). Urtica pulcherrima Roxb. (1832).

A shrub or small tree. Near the swamps of the forest. Representative specimen: Gazni, 31.10.2009, Ershad Tutul 455 (DUH).

\section{Nyctaginaceae}

Boerhaavia diffusa L., Sp. Pl. 1: 3 (1753). Boerhaavia repens L. (1753).

A perennial creeping or climbing herb. Rocky and sandy places of the forest. Representative specimen: Runctia, 1.11.2009, Ershad Tutul 599 (DUH). 


\section{Amaranthaceae}

Achyranthes aspera L., Sp. Pl. 1: 204 (1753). Cyathula geniculata Lour. (1790). Local name: Upatlengra.

An erect, perennial herb. On the hill slope. Representative specimen: Gazni, 31.10.2009, Ershad Tutul 483 (DUH).

Aerva lanata (L.) Juss. ex Schult., Syst. Veg. 15(5): 564 (1819). Aerva elegans Miq. (1849). Local name: Chaya.

An erect, perennial herb. On forest margin. Representative specimen: Gazni, 31.10.2009, Ershad Tutul 403 (DUH).

Alternanthera sessilis (L.) R. Br. ex Roem. \& Schult., Syst. 5: 554 (1819). Achyranthes villosa Blanco (1837). Local name: Highcha.

A much branched herb. Near the swamps of the forest. Representative specimen: Runctia, 1.11.2009, Ershad Tutul 508 (DUH).

Deeringia amaranthoides (Lamk.) Merr., Int. Rumph. Herb. Amb.: 211 (1917). Achyranthes amaranthoides Lamk. (1785).

A scandent or subscandent shrub. On the forest edges. Representative specimen: Runctia, 1.11.2009, Ershad Tutul 632 (DUH).

\section{Polygonaceae}

Persicaria barbata (L.) Hara, Fl. East. Himal.: 70 (1966). Polygonum barbatum L. (1753).

An ascending herb. Near the swamps of the forest. Representative specimen: Gazni, 31.10.2009, Ershad Tutul 473 (DUH).

Persicaria flaccida (Meissn.) H. Gross ex Loesen., Beih. Centralbl. 37: 112 (1919). Polygonum flaccidum Meissn. (1832). Local name: Lal-bishkatali.

An annual herb. Near the swamps of the forest. Representative specimen: Runctia, 1.11.2009, Ershad Tutul 590 (DUH).

\section{Clusiaceae}

Garcinia pedunculata Roxb. ex Buch.-Ham. in Brewster, Edinburgh J. Sci. 7: 45, t. 1 (1827).

A medium-sized, deciduous tree. On the hill slope. Representative specimen: Runctia, 1.11.2009, Ershad Tutul 628 (DUH).

\section{Elaeocarpaceae}

Elaeocarpus varunua Buch.-Ham. ex Masters in Hook. f., Fl. Brit. Ind. 1: 407 (1874). Local name: Belphoi.

A large to medium-sized evergreen tree. On the hill slope. Representative specimen: Gazni, 31.10.2009, Ershad Tutul 408 (DUH). 


\section{Tiliaceae}

Corchorus fascicularis Lamk., Encycl. 2: 104 (1786). Corchorus brachycarpus Guillemin (1831). Local name: Jangli-pat.

A suberect annual herb. Along sides of channel. Representative specimen: Runctia, 1.11.2009, Ershad Tutul 611 (DUH).

Grewia asiatica L., Mant. Pl.: 122 (1767). Grewia hainesiana Hole (1917).

A shrub or small tree. Common on the hill slope. Representative specimen: Gazni, 31.10.2009, Ershad Tutul 438 (DUH).

Triumfetta rhomboidea Jacq., Enum. Syst. Pl. Carib.: 22 (1760). Triumfetta bartramia L. (1759). Local name: Bon okra.

A herb or undershrub. Open places of the forest. Representative specimen: Gazni, 31.10.2009, Ershad Tutul 425 (DUH).

\section{Malvaceae}

Hibiscus mutabilis L., Sp. Pl.: 694 (1753). Local name: Sthal padma.

An erect robust shrub. On the hill top. Representative specimen: Runctia, 1.11.2009, Ershad Tutul 569 (DUH).

Hibiscus cannabinus L., Syst. Nat. ed. 10, 2: 1149 (1759). Local name: Mesta pat. An erect annual herb. On the hill top. Representative specimen: Runctia, 1.11.2009, Ershad Tutul 528 (DUH).

\section{Flacourtiaceae}

Flacourtia indica (Burm. f.) Merr., Interp. Rumph. Herb. Amb.: 377 (1917). Flacourtia rotundifolia Clos (1877).

A much-branched and dense deciduous thorny shrub. On the hill slope. Representative specimen: Gazni, 31.10.2009, Ershad Tutul 413 (DUH).

\section{Cucurbitaceae}

Hodgsonia macrocarpa (Blume) Cogn. in DC., Monog. Phan. 3: 349 (1881). Trichosanthes macrocarpa Blume (1826).

A robust, woody climbing herb. On the forests and thickets. Representative specimen: Runctia, 1.11.2009, Ershad Tutul 563 (DUH).

\section{Myrsinaceae}

Ardisia icara Wall. \& A. DC., Trans. Linn. Soc. 17: 125, t. 7 (1834). A large shrub. On the hill slope. Representative specimen: Gazni, 31.10.2009, Ershad Tutul 430 (DUH).

Maesa ramentacea (Roxb.) A. DC., Trans. Linn. Soc. 17: 133 (1834). Baeobotrys ramentacea Roxb. (1824). Local name: Bol-jakhandok. 
A large shrub or small tree. Moist shady places in the forest. Representative specimen: Runctia, 1.11.2009, Ershad Tutul 602 (DUH).

\section{Caesalpiniaceae}

Senna alata (L.) Roxb., Fl. Ind. 2: 349 (1832). Cassia alata L. (1753). Local name: Dadmardan.

A soft wooded shrubby plant. On the hill slope. Representative specimen: Gazni, 31.10.2009, Ershad Tutul 460 (DUH).

Senna tora (L.) Roxb., Fl. Ind. 2: 340 (1832). Cassia tora L. (1753). Local name: Chakunda.

An erect, profusely branched herb or undershrub. Common on the hill slope. Representative specimen: Runctia, 1.11.2009, Ershad Tutul 504 (DUH).

\section{Fabaceae}

Crotalaria alata D. Don, Prod. Fl. Nep.: 241 (1825).

A suberect herb. On the forest edges, also near swamps. Representative specimen: Runctia, 1.11.2009, Ershad Tutul 520 (DUH).

Desmodium gyroides (Roxb. ex Link) DC., Prodr. 2: 326 (1825). Hedysarum gyroides Roxb. ex Link (1822).

A long shrub. On the hill slope. Representative specimen: Gazni, 31.10.2009, Ershad Tutul 452 (DUH).

Desmodium heterocarpon (L.) DC., Prodr. 2: 337 (1825). Desmodium polycarpon (Poir.) DC. (1825).

An erect or suberect undershrub. On the hill slope. Representative specimen: Runctia, 1.11.2009, Ershad Tutul 605 (DUH).

Desmodium triflorum (L.) DC., Prodr. 2: 334 (1825). Hedysarum triflorum L. (1753).

A small herb. Open place on the hill slope. Representative specimen: Runctia, 1.11.2009, Ershad Tutul 551 (DUH).

Desmodium triquetrum (L.) DC., Prodr. 2: 326 (1825). Hedysarum triquetrum L. (1753).

A shrub, branches triquetrous, glabrescent. On the hill slope. Representative specimen: Gazni, 31.10.2009, Ershad Tutul 445 (DUH).

Desmodium velutinum (Willd.) DC., Prodr. 2: 328 (1825). Desmodium latifolium (Roxb.) DC. (1825).

An erect undershrub. On the hill slope. Representative specimen: Runctia, 1.11.2009, Ershad Tutul 518 (DUH). 
Desmodium triquetrum (L.) DC. subsp. alatum (DC.) Prain, J. Asiat. Soc. Beng. 66: 390 (1897). Desmodium alatum DC. (1825).

A shrub with triquetrous branches. On the hill slope. Representative specimen: Runctia, 1.11.2009, Ershad Tutul 572 (DUH).

Pueraria phaseoloides (Roxb.) Benth., J. Linn. Soc. Bot. 9: 125 (1867). Dolichos phaseoloides Roxb. (1832).

A much-branched twining, woody climber. On the hill slope. Representative specimen: Runctia, 1.11.2009, Ershad Tutul 604 (DUH).

Pueraria phaseoloides (Roxb.) Benth. var. subspicata (Benth.) van der Maesen, Agric. Univ. Wageningen Pap. 81(1): 84 (1985). Pueraria subspicata (Benth.) Benth. (1867).

A twinning herb. On the hill slope. Representative specimen: Runctia, 1.11.2009, Ershad Tutul 605 (DUH).

Spatholobus acuminatus Benth. in Miq., Pl. Jungh.: 238 (1852). Butea squamiger (Prain) Blatter (1929).

A large climber, with glabrous branches. On the hill slope. Representative specimen: Gazni, 31.10.2009, Ershad Tutul 424 (DUH).

Spatholobus parviflorus (Roxb. ex DC.) O. Kuntze, Rev. Gen. Pl.: 205 (1891). Butea parviflora Roxb. ex DC. (1825).

An extensive evergreen climber. On the plants in hill slope. Representative specimen: Gazni, 31.10.2009, Ershad Tutul 469 (DUH).

Uraria lagopus DC., Ann. Sc. Nat. Ser. 1, 4: 100 (1825). Uraria rependa Wall. ex Benth. (1832).

An erect undershrub. On the hill slope. Representative specimen: Runctia, 1.11.2009, Ershad Tutul 562 (DUH).

Vigna vexillata (L.) A. Rich., Hist. Fis. Polit. Nat. 1, Cuba 11: 191 (1445). Phaseolus vexillata L. (1753).

A perennial climbing or trailing herb. On the hill slope. Representative specimen: Gazni, 31.10.2009, Ershad Tutul 416 (DUH).

\section{Myrtaceae}

Syzygium balsameum (Wight) Walp., Repert. 2: 17 (1843). Eugenia balsamea Wight (1841). Local name: Buti jam.

A large shrub or small tree with light grey bark. Near the swamps of the forest. Representative specimen: Gazni, 31.10.2009, Ershad Tutul 489 (DUH).

\section{Onagraceae}

Ludwigia perennis L., Sp. Pl.: 119 (1753). Jussiaea perennis (L.) Brenan (1953).

An erect, unbranched herb. Near the swamps of the forest. Representative specimen: Runctia, 1.11.2009, Ershad Tutul 544 (DUH). 


\section{Melastomataceae}

Osbeckia rostrata D. Don, Prod. Fl. Nepal: 221 (1825). Osbeckia stellata var. rostrata (D. Don) Hansen (1977).

A small shrub. On the forest edges. Representative specimen: Gazni, 31.10.2009, Ershad Tutul 451(DUH).

\section{Combretaceae}

Calycopteris floribunda (Roxb.) Lamk., Enc. Meth. Bot. Suppl. 2: 41 (1811). Getonia floribunda Roxb. (1798).

A diffuse or scandent shrub. On the hill top of the forest. Representative specimen: Gazni, 31.10.2009, Ershad Tutul 457 (DUH).

\section{Euphorbiaceae}

Glochidion velutinum Wight, Ic. Pl. Ind. Or. 5(2): 29, t. 1907, f. 2 (1852). Phyllanthus velutinus (Wight) Muell.-Arg. (1865).

A small evergreen tree. On the hill slope. Representative specimen: Gazni, 1.11.2009, Ershad Tutul 454 (DUH).

Jatropha curcas L., Sp. Pl. 2: 1006 (1762). Local name: Sadajeol.

A glabrous, soft-wooded shrub or small tree. On the forest margin. Representative specimen: Runctia, 1.11.2009, Ershad Tutul 529 (DUH).

Phyllanthus acidus (L.) Skeels, U.S. Dept. Agric. Bur. Pl. Ind. Bull. 148: 17 (1909). Averrhoa acida L. (1753).

A deciduous glabrous tree. On the hill slope. Representative specimen: Runctia, 1.11.2009, Ershad Tutul 515 (DUH).

\section{Rhamnaceae}

Ziziphus rugosa Lamk., Encycl. 3: 319 (1789). Ziziphus tomentosa Roxb. (1820). Local name: Jangli boroi.

A prickly shrub to small tree. On the hill slope. Representative specimen: Gazni, 31.10.2009, Ershad Tutul 442 (DUH).

\section{Vitaceae}

Ampelopsis glandulosa (Roxb.) Momiyama, Fl. Eastern Himalaya 2: 78 (1979). Vitis glandulosa (Roxb.) Wall. (1824).

A slender, branched climber. On the hill slopes. Representative specimen: Gazni, 31.10.2009, Ershad Tutul 444 (DUH).

\section{Anacardiaceae}

Holigarna longifolia Roxb., Fl. Ind. 2: 80 (1824). Local name: Barola. 
A tall tree with glabrous ash-coloured bark. Moist places in the forest. Representative specimen: Gazni, 31.10.2009, Ershad Tutul 465 (DUH).

\section{Rutaceae}

Murraya koenigii (L.) Spreng., Syst. Veg. 2: 315 (1825). Chalcas koenigii (L.) Kurz (1875). Local name: Currypata.

A large shrub or small tree. Moist places of the forest. Representative specimen: Gazni, 31.10.2009, Ershad Tutul 414 (DUH).

\section{Convolvulaceae}

Argyreia argentea (Roxb.) Choisy, Mem. Soc. Phys. Geneve. 6: 418 (1833). Lettsomea argentea Roxb. (1824).

A common large climber. On the hill slope of the forest. Representative specimen: Gazni, 31.10.2009, Ershad Tutul 461 (DUH).

Aniseia martinicensis (Jacq.) Choisy, Mem. Soc. Phys. Geneve. 8: 66 (1838). Convolvulus martinicensis Jacq. (1763).

A twiner. On the hill slope of the forest. Representative specimen: Runctia, 1.11.2009, Ershad Tutul 554 (DUH).

\section{Verbenaceae}

Clerodendrum indicum (L.) O. Kuntze, Revis. Gen. Pl. 2: 506 (1891). Clerodendrum verticillatum D. Don (1825).

A shrub. On the hill top of the forest. Representative specimen: Runctia, 1.11.2009, Ershad Tutul 579 (DUH).

\section{Lamiaceae}

Anisomeles malabarica (L.) R. Br. ex Sims, Bot. Mag.: t. 2071 (1819). Anisomeles intermedia Wight ex Benth. (1835).

A tall shrubby plant. Common on the hill slope. Representative specimen: Gazni, 31.10.2009, Ershad Tutul 435 (DUH).

Hyptis suaveolens (L.) Poit., Ann. Mus. Par. 7: 472, t. 29 (1806). Ballota suaveolens L. (1759). Local name: Tokma.

A sweet smelling rigid herb. Along the forest edges. Representative specimen: Runctia, 1.11.2009, Ershad Tutul 581 (DUH).

Ocimum americanum L., Cent. Pl. 1: 15 (1753). Ocimum canum Sims (1823). Local name: Bon tulshi.

An erect, aromatic herb. Open places of the forest. Representative specimen: Runctia, 1.11.2009, Ershad Tutul 608 (DUH). 
Pogostemon paniculatus (Willd.) Benth. in Wall., Pl. As. Rar. 2: 30 (1830). Elsholtzia paniculata Willd. (1801).

An erect, branched herb. On the hill slope. Representative specimen: Runctia, 1.11.2009, Ershad Tutul 523 (DUH).

\section{Scrophulariaceae}

Limnophila heterophylla (Roxb.) Benth., Scroph. Ind.: 25 (1835). Columnea heterophylla Roxb. (1832).

An aquatic herb. Near the swamps of the forest. Representative specimen: Gazni, 31.10.2009, Ershad Tutul 499 (DUH).

Limnophila repens (Benth.) Benth. in DC., Prodr. 10: 387 (1846). Limnophila conferta Benth. (1846).

An aquatic herb. Near the swamps of the forest. Representative specimen: Runctia, 1.11.2009, Ershad Tutul 555 (DUH).

Limnophila sessiliflora (Vahl) Blume, Bijdr.: 749 (1826). Hottonia sessiliflora Vahl (1791).

An aquatic herb. Near the swamps of the forest. Representative specimen: Runctia, 1.11.2009, Ershad Tutul 591 (DUH).

Lindernia crustacea (L.) F. Muell., Census Austral. Pl. 1: 97 (1882). Capraria crustacea L. (1767).

A small herb. Near the swamps of the forest. Representative specimen: Runctia, 1.11.2009, Ershad Tutul 513 (DUH).

Lindernia procumbens (Krocker) Philcox, Taxon 14: 30 (1965). Anagalloides procumbens Krocker (1790).

An aquatic herb. Near the swamps of the forest. Representative specimen: Runctia, 1.11.2009, Ershad Tutul 560 (DUH).

\section{Acanthaceae}

Barleria prionitis L., Sp. Pl.: 636 (1753). Barleria flava Jacq. (1781).

A branched shrub. On the hill slope. Representative specimen: Runctia, 1.11.2009, Ershad Tutul 521 (DUH).

Lepidagathis incurva Buch.-Ham. ex D. Don, Prodr. Fl. Nep.: 119 (1825). Lepidagathis hyalina Nees (1832).

A perennial, suberect herb. Moist places in the forest. Representative specimen: Gazni, 31.10.2009, Ershad Tutul 409 (DUH).

Rungia pectinata (L.) Nees in DC., Prodr. 11: 469 (1847). Rungia parviflora var. pectinata (L.) C. B. Clarke (1885). Local name: Birlongopark. 
A much branched herb. On the hill slope. Representative specimen: Runctia, 1.11.2009, Ershad Tutul 594 (DUH).

Thunbergia fragrans Roxb., Pl. Corom. 1: 47, t. 67 (1795). Thunbergia fragrans Roxb. var. laevis (Nees) C. B. Clarke (1884).

A twiner or climber. On the Jarul tree of this forest. Representative specimen: Runctia, 1.11.2009, Ershad Tutul 565 (DUH).

\section{Lentibulariaceae}

Utricularia bifida L., Sp. Pl. 1: 18 (1753). Utricularia recurva Lour. (1790). Local name: Chotojhanjhi.

A very small, annual insectivorous herb. On moist places near the water body. Representative specimen: Gazni, 1.11.2009, Ershad Tutul 527 (DUH).

\section{Rubiaceae}

Dentella repens (L.) J. R. \& G. Forst., Char. Gen. Pl. Ins. Mar. Austr.: 26, t. 13 (1776). Oldenlandia repens L. (1768).

An aquatic herb. Near the swamps of the forest. Representative specimen: Runctia, 1.11.2009, Ershad Tutul 509 (DUH).

\section{Asteraceae}

Sphaeranthus indicus L., Sp. Pl. ed. 2: 1314 (1762). Sphaeranthus hirtus Willd. (1804).

An erect, annual herb. Cultivated by Kuch tribes in their inhabitants. Representative specimen: Gazni, 1.11.2009, Ershad Tutul 550 (DUH).

Spilanthes calva DC. in Wight, Contrib. : 19 (1834). Spilanthes acmella auct. non. L., Thw. (1860).

An annual, glabrous herb. On the forest edges. Representative specimen: Runctia, 1.11.2009, Ershad Tutul 517 (DUH).

Synedrella nodiflora (L.) Gaertn., Fruct. 2: 456, t. 171 (1791). Verbesina nodiflora L. (1787). Local name: Highcha.

An erect, branched, pubescent herb. On the hill slope of the forest. Representative specimen: Runctia, 1.11.2009, Ershad Tutul 603 (DUH).

\section{LILIOPSIDA (MONOCOTS)}

\section{Xyridaceae}

Xyris indica L., Sp. Pl.: 42 (1753). Xyris robusta Mart (1832).

A tufted herb. Marshy areas of the forest. Representative specimen: Runctia, 1.11.2009, Ershad Tutul 536 (DUH). 


\section{Commelinaceae}

Commelina paleata Hassk., Pl. Jungh.: 139 (1852).

A long creeping herb. On the wetlands of the forest. Representative specimen: Runctia, 1.11.2009, Ershad Tutul 598 (DUH).

Floscopa scandens Lour., Fl. Cochin.: 192 (1790). Dithyrocarpus rothii Wight (1836).

A perennial herb. Near the swamps and on the edges of the forest. Representative specimen: Runctia, 1.11.2009, Ershad Tutul 589 (DUH).

\section{Cyperaceae}

Cyperus cuspidatus Kunth in Humb., Bonpl. \& Kunth, Nov. Gen. \& Sp. Pl. 1: 204 (1815). Cyperus uncinatus Camus (1912).

An annual herb. On the edges and near the swamps of the forest. Representative specimen: Runctia, 1.11.2009, Ershad Tutul 510 (DUH).

Cyperus haspan L., Sp. Pl. ed. 1: 45 (1753). Cyperus micranthus Presl. (1828).

An annual or perennial herb. Near the swamps of the forest. Representative specimen: Runctia, 1.11.2009, Ershad Tutul 595 (DUH).

Cyperus iria L., Sp. Pl. ed. 1: 45 (1753). Cyperus diaphaniria Steud. (1855).

An annual or perennial herb. On the edges of the forest. Representative specimen: Runctia, 1.11.2009, Ershad Tutul 537 (DUH).

Cyperus pilosus Vahl, Enum. Pl. 2: 354 (1806). Cyperus obliquus Nees (1834).

An annual herb. On the edges and near the wetland of the forest. Representative specimen: Runctia, 1.11.2009, Ershad Tutul 535 (DUH).

Cyperus procerus Rottb., Descr. \& Icon. Rar. Nov. Pl. 1: 29, t. 5, f. 3 (1773). Pycreus puncticulatus Ridl. (1907).

A perennial herb. Near the swamps of the forest. Representative specimen: Runctia, 1.11.2009, Ershad Tutul 585 (DUH).

Cyperus tenuispica Steud., Syn. Pl. Glum. 2: 11 (1855). Cyperus flavidus (non Retz.) C. B. Clarke (1893).

An annual or perennial herb. Near the swamps and along the edges of the forest. Representative specimen: Gazni, 31.10.2009, Ershad Tutul 501 (DUH).

Fimbristylis dichotoma (L.) Vahl subsp. dichotoma, Enum. Pl. 2:287 (1806). Scirpus dichotoma L. (1753).

An annual or perennial herb. Near the swamps and along the margin of the forest. Representative specimen: Gazni, 31.10.2009, Ershad Tutul 500 (DUH).

Fimbristylis miliacea (L.) Vahl, Enum. Pl. 2:287 (1806). Scirpus miliacea L. (1759).

An annual or perennial herb. Near the swamps and wetlands of the forest. Representative specimen: Gazni, 1.11.2009, Ershad Tutul 534 (DUH). 
Fimbristylis ovata (Burm. f.) Kern, Blumea 15: 126 (1967). Carex ovata Burm. f. (1768).

A perennial herb. Near the swamps and wetlands of the forest. Representative specimen: Gazni, 1.11.2009, Ershad Tutul 540 (DUH).

Fuirena ciliaris (L.) Roxb., Fl. Ind. ed. Carey 1: 184 (1820). Scirpus ciliaris L. (1771).

An annual herb. Near the swamps of the forest. Representative specimen: Gazni, 1.11.2009, Ershad Tutul 542 (DUH).

Kyllinga bulbosa Beauv., Fl. d'Oware \& Benin 1:11 t. 8, f. 1 (1804). Cyperus triceps (Rottb.) Endl. (1842).

A perennial herb. Open places and edges of the forest. Representative specimen: Gazni, 31.10.2009, Ershad Tutul 459 (DUH).

Pycreus stramineus (Nees) C. B. Clarke in Hook. f., Fl. Brit. Ind. 6: 589 (1893). Cyperus stramineus Nees (1834).

An annual herb. Along the wetlands and margin of the forest. Representative specimen: Runctia, 1.11.2009, Ershad Tutul 537 (DUH).

\section{Poaceae}

Arthraxon nudus (Nees ex Steud.) Hochst., Flora 39: 188 (1856). Bathratherum nudum Nees ex Steud. (1854).

An annual creeping grass, rooting at the nodes. Near swamps, and moist and shady places. Representative specimen: Gazni, 31.10.2009, Ershad Tutul 491 (DUH).

Cyrtococcum accrescens (Trin.) Stapf in Hook., Ic. Pl.: sub t. 3096 (1922). Panicum accrescens Trin. (1828).

A scrambling grass. Shady places along the forest edges. Representative specimen: Gazni, 31.10.2009, Ershad Tutul 476 (DUH).

Eragrostis gangetica (Roxb.) Steud., Syn. Pl. Glum. 1: 266 (1854). Poa gangetica Roxb. (1820).

An annual or short-lived perennial grass. Near swamps, and open places of the forest. Representative specimen: Gazni, 31.10.2009, Ershad Tutul 495 (DUH).

Eragrostis japonica (Thunb.) Trin., Mem. Acad. Sci. Petersb. Ser. 6, 1: 405 (1830). Poa japonica Thunb. (1784).

An annual or short-lived perennial grass. Near swamps of the forest. Representative specimen: Runctia, 1.11.2009, Ershad Tutul 625 (DUH).

Isachne globosa (Thunb.) O. Kuntze, Rev. Gen. Pl. 2: 778 (1891). Milium globosum Thunb. (1784).

An annual or short-lived perennial grass. Near swamps, and open places of the forest. Representative specimen: Gazni, 31.10.2009, Ershad Tutul 496 (DUH). 
Oplismenus compositus (L.) P. Beauv., Ess. Agrost. 54: 169 (1812). Panicum compositum L. (1753).

A grass with tall and creeping culms. Shady places along edges of the forest. Representative specimen: Gazni, 31.10.2009, Ershad Tutul 405 (DUH).

Panicum brevifolium L., Sp. Pl. ed. 1, 1: 59 (1753). Panicum ovalifolium Poir. (1816).

A grass with tall culms. Shady places along edges and near the swamps of the forest. Representative specimen: Gazni, 31.10.2009, Ershad Tutul 401(DUH).

Panicum notatum Retz., Obs. Bot. 4: 18 (1786). Panicum courtallense Nees \& Wall. (1854).

A perennial grass with tall culms. On the forest edges and near swamps. Representative specimen: Gazni, 31.10.2009, Ershad Tutul 477 (DUH).

Paspalum cartilagineum J. S. Presl ex C. B. Presl, Rel. Haenk. 1: 216 (1830).

A perennial grass with erect culms. Open places of the forest. Representative specimen: Runctia, 1.11.2009, Ershad Tutul 511 (DUH).

Sporobolus indicus R. Br., Prodr.: 170 (1810). Sporobolus elongatus R. Br. (1810).

A perennial grass with tufted culms. Open places of the forest. Representative specimen: Runctia, 1.11.2009, Ershad Tutul 547 (DUH).

\section{Arecaceae}

Calamus guruba Buch.-Ham. ex Martius, Hist. Nat. Palm. 3: 211 (1838). Calamus nitidus Martius (1853). Local name: Jalibet.

A scandent, spiny rattan. On the edges of the forest. Representative specimen: Gazni, 31.10.2009, Ershad Tutul 420 (DUH).

\section{Liliaceae}

Molinera recurvata (Dryand.) Herbert, Amaryl.: 84 (1834). Curculigo recurvata Dryand. (1811).

A stout herb. On the hill slopes of the forest. Representative specimen: Runctia, 1.11.2009, Ershad Tutul 634 (DUH).

\section{Smilacaceae}

Smilax ocreata A. DC. in DC., Monogr. Phan. 1: 191 (1878). Smilax roxburghiana Wall. (1831-1832).

A woody climber. On the hill slopes of the forest. Representative specimen: Gazni, 31.10.2009, Ershad Tutul 447 (DUH).

Smilax pseudo-china L., Sp. Pl. 2: 1031 (1753). Smilax leptanthera Pennell (1916).

An annual climber. On the hill slopes and near channel of the forest. Representative specimen: Gazni, 31.10.2009, Ershad Tutul 479 (DUH). 


\section{Results and Discussion}

The present study revealed the occurrence of additional 100 angiosperm species under 75 genera in 40 families, amongst which Magnoliopsida is represented by 71 species under 56 genera and 33 families, whereas Liliopsida is represented by 29 species, 19 genera and 7 families. These species exhibit in diverse life forms in the area, viz., herbs are represented by 54, shrubs by 21, trees 13 and climbers by 12 species. The family Fabaceae appears as the largest in Magnoliopsida represented by 13 species, whereas the Cyperaceae is the largest family in Liliopsida comprising 12 species in this addition. Among the genera Desmodium is the largest in dicots comprising $D$. gyroides, $D$. heterocarpon, D. triflorum, D. triquetrum, D. triquetrum subsp. alatum and D. velutinum, whereas Cyperus is the largest in monocots possessing C. cuspidatus, C. haspan, C. iria, C. pilosus, C. procerus and C. tenuispica. The low lands are dominated by the members of the family Cyperaceae and Poaceae.

In the present study Holigarna longifolia, a member of the family Anacardiaceae has been reported as threatened from Runctia sal forest, whereas previous studies have reported Cymbidium aloifolium and Rauvolfia serpentina as threatened from the forest (Tutul et al., 2009, 2010). These species recorded from the Runctia forest have been included in the Red list of vascular plants of Bangladesh (Khan et al., 2001).

At present the floral diversity of the forest is in great risk because of many threats as observed during field visits including illegal sand and stone collection from forest bed, clear felling and exotic monoculture plantation, frequent forest fire during dry season, illegal logging, fire wood collection, over-exploitation of the medicinal plants, lack of awareness among the local people etc. Therefore, the following recommendations should be adopted for the sake of better management of the forest and botanical diversity: i) steps should be undertaken to protect the habitats of the species; ii) conservation priorities should be given to the rare, threatened and endangered species; iii) distribution map of threatened plants should be made on priority basis that will facilitate accurate location and home range of threatened species in the forest; iv) public awareness to be built up to preserve floral diversity, particularly the medicinal plants; v) monitoring activities should be strengthened; and vi) in severe cases, ex situ conservation measure for particular species may be applied for replicating the population.

\section{References}

Cronquist, A. 1981. An integrated system of classification of flowering plants. Columbia University Press, New York. 1262 pp.

Dassanayake, M.D. and Fosberg, F.R. (eds.). 1980-1985. A Revised Handbook to the Flora of Ceylon, Vols. 1-5. Amerind Publishing Co. Pvt. Ltd., New Delhi.

Hajra, P.K., Nair, V.J. and Daniel, P. (eds.). 1997. Flora of India, Vol. 4. Botanical Survey of India, Calcutta. $561 \mathrm{pp}$. 
Hooker, J.D. 1872-1897. The Flora of British India, Vols. 1-7. Bishen Singh Mahendra Pal Singh, Dehra Dun, India.

Kanjilal, U.N., Kanjilal, P.C. and Das, A. 1934. Flora of Assam, Vol. 1. A Von Book Company, Delhi, India. $386 \mathrm{pp}$.

Kanjilal, U.N., Kanjilal, P.C. and Das, A. 1938. Flora of Assam, Vol. 2. A Von Book Company, Delhi, India. 409 pp.

Kanjilal, U.N., Das, A., Kanjilal, P.C. and De, R.N. 1939. Flora of Assam, Vol. 3. A Von Book Company, Delhi, India. 578 pp.

Kanjilal, U.N., Kanjilal, P.C., De, R.N. and Das, A. 1940. Flora of Assam, Vol. 4. A Von Book Company, Delhi, India. 377 pp.

Khan, M.S. (ed.). 1972-1987. Flora of Bangladesh, Nos. 1-39. Bangladesh National Herbarium, BARC, Dhaka.

Khan, M.S. and Rahman, M.M. (eds.). 1989-2002. Flora of Bangladesh, Nos. 40-53. Bangladesh National Herbarium, Dhaka.

Khan, M.S., Rahman, M.M. and Ali, A.A. (eds.). 2001. Red Data Book of Vascular Plants of Bangladesh. Bangladesh National Herbarium, Dhaka. 179 pp.

Prain, D. 1903. Bengal Plants. Vols. 1\&2 (Ind. Repr. 1981). Bishen Singh Mahendra Pal Singh, Dehra Dun, India.

Singh, N.P., Vohra, J.N., Hajra, P.K. and Singh, D.K. (eds.). 2000. Flora of India, Vol. 5. Botanical Survey of India, Calcutta. 577 pp.

Tutul, E., Uddin, M.Z., Rahman, M.O. and Hassan, M.A. 2009. Angiospermic flora of Runctia sal forest, Bangladesh. I. Liliopsida (Monocots). Bangladesh J. Plant Taxon. 16(1): 83-90.

Tutul, E., Uddin, M.Z., Rahman, M.O. and Hassan, M.A. 2010. Angiospermic flora of Runctia sal forest, Bangladesh. II. Magnoliopsida (Dicots). Bangladesh J. Plant Taxon. 17(1): 33-53. 